\title{
Pan-RAF Kinase Inhibitor TAK-580
}

National Cancer Institute

\section{Source}

National Cancer Institute. pan-RAF Kinase Inhibitor TAK-580. NCI Thesaurus. Code C106254.

An orally available inhibitor of A-Raf, B-Raf and C-Raf protein kinases, with potential antineoplastic activity. Upon administration, pan-RAF kinase inhibitor TAK-580 inhibits Rafmediated signal transduction pathways, which may lead to an inhibition of tumor cell growth. Raf protein kinases play a key role in the RAF/MEK/ERK signaling pathway, which is often deregulated in human cancers and plays a key role in tumor cell proliferation and survival. 